\title{
Assessment and Optimization of Formaldehyde Removal Using Tidal Flow Constructed Wetlands
}

\author{
Zhihao Si, Xinshan Song*, Yuhui Wang, Xin Cao, \\ Yufeng Zhao, Xiaoyan Ge, Yifei Wang
}

College of Environmental Science and Engineering, State Environmental Protection Engineering Center for Pollution Treatment and Control in Textile Industry, Donghua University, Shanghai, China

Received: 30 December 2019

Accepted: 14 May 2020

\begin{abstract}
Assessment of formaldehyde (HCHO) removal using constructed wetlands (CWs) was scarcely ever reported. Here, the feasibility of HCHO removal was studied in tidal flow CWs (TFCWs) with/without wetland vegetation (Canna indica L.). The HCHO removal efficiencies of TFCWs with various initial loads $\left(25,50,75\right.$, and $\left.100 \mathrm{mg} \mathrm{L}^{-1}\right)$ were investigated, then the impact of influent $\mathrm{pH}$ and DO values on $\mathrm{HCHO}$ removal was evaluated. Results showed that microbiological degradation was the main HCHO removal pathway. The aerobic condition (DO concentration $>4 \mathrm{mg} \mathrm{L}^{-1}$ ) and neutral/weak alkaline $\mathrm{pH}$ (approximately 7-8) was favorable for the HCHO removal. In order to upgrade the HCHO removal potential, a two-stage cyclic CW (t-TFCW) was designed. For an influent $\mathrm{HCHO}$ concentration around $100 \mathrm{mg} \mathrm{L}^{-1}$, t-TFCW showed a stable and efficient $\mathrm{HCHO}$ removal performance, where the average HCHO removal rate was found to be $98.1 \%$ after a 6 - hour treatment.
\end{abstract}

Keywords: wastewater treatment, formaldehyde removal, constructed wetlands, tidal operation

\section{Introduction}

Formaldehyde (HCHO) was known as a carcinogenic volatile organic compound (VOC), which exists in organisms or external environments in the forms of gaseous, dissolved, or combination state [1]. The HCHO water pollution is generally present in the discharge water of chemical and pharmaceutical industries. The condensation water of phenol-formaldehyde, urea-

*e-mail: newmountain@dhu.edu.cn formaldehyde, and melamine-formaldehyde resins, as well as the wash water of urotropin synthesis were the typical high $\mathrm{HCHO}$-containing wastewater [2]. In addition, the formalin solution used in biological and medical fields for preservative treatment is also the emission source of $\mathrm{HCHO}$ water pollution [3].

Up to the present, many scholars have been devoted to the HCHO pollution abatement. Various adsorbents such as bio-char and Alumina nanoparticles were developed to capture the HCHO from the air and contaminated water [4, 5]. However, the approach of physical adsorption is not suitable for practical engineering applications because of the reversibility 
of the adsorption process. Also, the removal of $\mathrm{HCHO}$ via advanced oxidation processes, including Fenton reagent oxidation, photocatalytic oxidation, wet oxidation process, and other catalytic oxidation with efficient catalysts, have been widely studied [6]. Even though these methods exhibit a high-performance for HCHO removal, they are costly and pose a risk of secondary pollution. Compared with the methods mentioned above, biological treatment can achieve considerable and sustainable $\mathrm{HCHO}$ removal at a low cost. Previous studies have demonstrated that sustainable removal of low concentration $\mathrm{HCHO}$ can be achieved by phytoremediation [7]. To date, a few microbiological treatment cases for the HCHO removal have been reported. For example, with the adding of methanol, an efficient $\mathrm{HCHO}$ degradation was achieved in a membrane-aerated biofilm reactor [8]. Maria et al. [9] proved that the presence of a static magnetic field increased the HCHO removal efficiency of activated sludge. Moreover, an anaerobic sequencing batch biofilm reactor was reported to be an efficient device for $\mathrm{HCHO}$ removal, while the disadvantage is that the anaerobic $\mathrm{HCHO}$ degradation process resulted in the accumulation of byproducts [10]. Since both plants and microorganisms have the potential to eliminate $\mathrm{HCHO}$ pollution, the combined remediation of plant and microbe may be a practical approach for treating $\mathrm{HCHO}$ wastewater.

CWs are a reliable wastewater treatment technology with low investment and low energy consumption, in which the wetland vegetation and the domesticated microbial communities have the potential to remove a wide variety of pollutants from wastewater. Many studies indicated that CWs could remove dissolved organic matter (DOM) efficiently [11], and also showed a high-performance for the removal of toxic organic pollutants [12]. However, research on HCHO removal using CWs was still scarcely reported. Only one previous study proposed that CWs were probably a convenient device for HCHO removal [13]. Therefore, there is a lack of investigation on HCHO removal using CWs, and there is no report on the optimization of wetland structure to obtain an efficient $\mathrm{HCHO}$ removal.

This study aims to evaluate the potential of $\mathrm{HCHO}$ removal using TFCWs. The removal efficiencies of $\mathrm{HCHO}$ at various influent concentrations $(25,50,75$, and $100 \mathrm{mg} \mathrm{L}^{-1}$ ) were determined, as well as for TFCWs of non-vegetated and vegetated. Moreover, the impact of influent $\mathrm{pH}$ and $\mathrm{DO}$ on $\mathrm{HCHO}$ removal was assessed in a TFCW with vegetation. Based on the exploration in the TFCWs, a two-stage cyclic TFCW was developed, which showed high efficiency of $\mathrm{HCHO}$ removal.

\section{Material and Methods}

\section{Laboratory-Scale Wetlands and Synthetic Wastewater}

Polyvinyl chloride (PVC) cylinders with a height of $52 \mathrm{~cm}$ and an internal diameter of $16 \mathrm{~cm}$ were used to simulate lab-scale vertical flow wetland devices

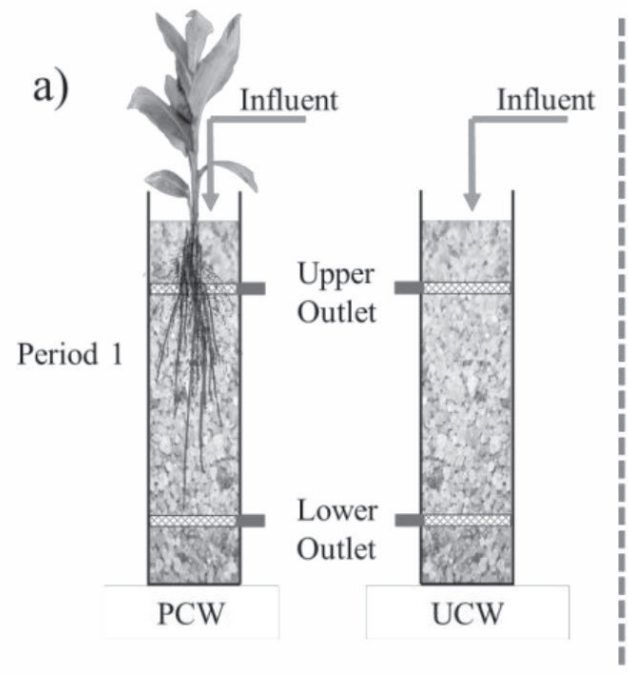

b)

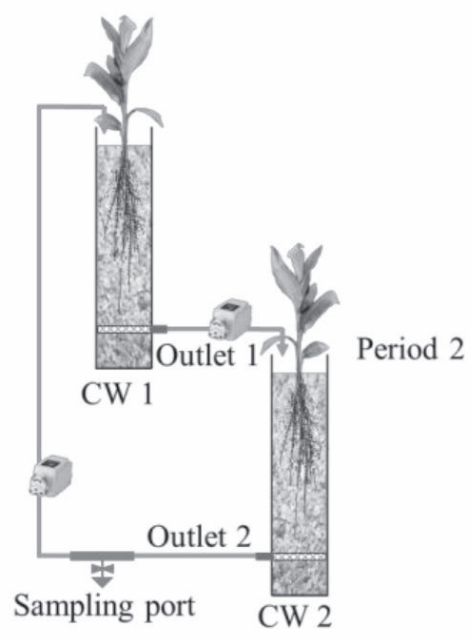

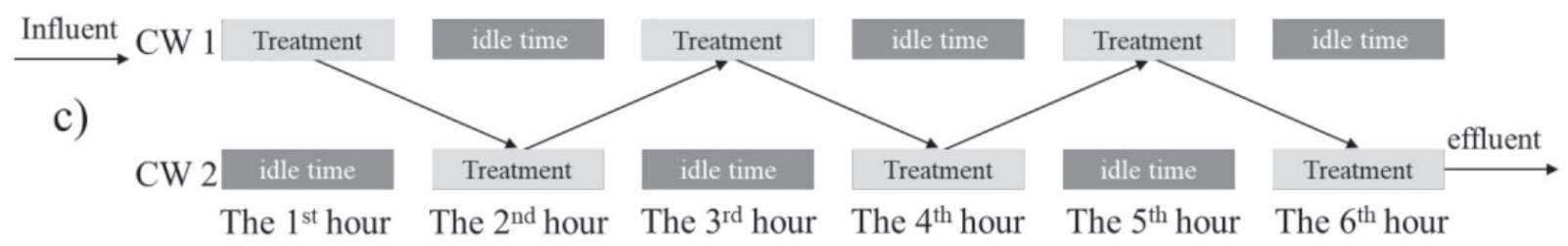

Fig. 1. Schematic diagram of the experimental device. a) The TFCW used during period 1 and 2; b) The two-stage cyclic TFCW used during period 3; c) The operation strategy of a two-stage cyclic TFCW in period 3 (the effluents were continuously recycled between CW 1 and $\mathrm{CW} 2$, and each single TFCW can atmospheric reoxygenation during the 1-hour idle time). 
(Fig. 1a). The four cylinders were filled with quartz sand (diameter: 3 to $5 \mathrm{~mm}$ ) up to $50 \mathrm{~cm}$ (effective volume: $2.5 \pm 0.2 \mathrm{~L}$ ). Two outlets were set on each TFCW. Namely, $8 \mathrm{~cm}$ and $40 \mathrm{~cm}$ above the bottom of the device was named as Upper outlet and Lower outlet, respectively. Disease-free Canna indices L. with similar size $(110 \pm 10 \mathrm{~g}$ fresh weight for each) was planted in two reactors named PCW, while the other two reactors were left unplanted (UCW). The CWs were inoculated with activated sludge from Songjiang sewage-treatment plant (Songjiang District, Shanghai). During the domestication stage (lasts for 21 days), synthetic wastewater was prepared with tap water, and the composition was as follows $\left(\mathrm{mg} \mathrm{L}^{-1}\right)$ : formaldehyde, 50; Glucose, 105; $\mathrm{NH}_{4} \mathrm{Cl}, 34 ; \mathrm{KNO}_{3}$, $108 ; \mathrm{KH}_{2} \mathrm{PO}_{4}, 7 ; \mathrm{MgCl}_{2} \cdot 6 \mathrm{H}_{2} \mathrm{O}, 60 ; \mathrm{ZnCl}_{2}, 11 ; \mathrm{CaCl}_{2}, 18$; $\mathrm{CuSO}_{4} \cdot 5 \mathrm{H}_{2} \mathrm{O}, 0.03 ; \mathrm{FeSO}_{4} \cdot 7 \mathrm{H}_{2} \mathrm{O}, 0.25 ; \mathrm{MnSO}_{4} \cdot \mathrm{H}_{2} \mathrm{O}, 1$; $\mathrm{Na}_{2} \mathrm{MoO}_{4} \cdot 2 \mathrm{H}_{2} \mathrm{O}, 0.3$; $\mathrm{CoCl}_{2} \cdot 6 \mathrm{H}_{2} \mathrm{O}, 0.03$; and $\mathrm{H}_{3} \mathrm{BO}_{4}, 6$.

\section{Experimental Conditions and Operation}

CW reactors were placed on the balcony from April to July, and the average air temperature was around $25^{\circ} \mathrm{C}$. Synthetic wastewater was fed into the $\mathrm{CW}$ reactors under a tidal flow mode, with a hydraulic residence time (HRT) of $24 \mathrm{~h}$. For each inflow event, the initial $\mathrm{HCHO}$ concentration in $\mathrm{CWs}$ was stabilized by three complete flushes with the corresponding synthetic wastewater, before the final inflow. The influent $\mathrm{pH}$ values were adjusted using $2 \mathrm{M} \mathrm{NaOH}$ or $\mathrm{HCl}$ solution. The influent DO was controlled by purging with $\mathrm{N}_{2}$ or aeration, before adding the $\mathrm{HCHO}$ solution. The experiments were divided into 3 periods. In period 1, the $\mathrm{HCHO}$ removal efficiency at different initial HCHO concentrations $(25,50,75$, and $100 \mathrm{mg} \mathrm{L}^{-1}$ ) was investigated. The effluents were collected from the Upper and Lower outlets hourly. During period 2, the impact of influent $\mathrm{pH}$ (around 5, 6, 7, 8 and 9) and DO (approximately 2, 3, 4, 5, 6, 7, 8,9 , and 10) on HCHO removal was assessed in PCWs with a 6 h-HRT. For period 3, a two-stage cyclic TFCW which consists of two single TFCWs was constructed to optimize the HCHO removal (Fig. 1b). The operation strategy (Fig. $1 \mathrm{~b}$ and c) was conducted to: firstly, simulated wastewater was fed into $\mathrm{CW} 1$. After that, the effluents were continuously recycled between $\mathrm{CW} 1$ and CW 2 by pumps hourly. Thus, each $\mathrm{CW}$ has an idle time of 1 hour for the atmospheric reoxygenation before the wastewater inflow.

\section{Sampling and Analyses}

Before the determination of water quality parameters, all the water samples were filtered through the $0.45-\mu \mathrm{m}$ filter membrane (Navigator, China). The $\mathrm{pH}, \mathrm{DO}$ in influents and effluents were measured with a dual-probe multi-parameter meter (HQ40d, Hach, USA). HCHO concentration in wastewater was measured with Nash reagent [13]. A portable HCHO meter (RCH-188, Ruichao, China) was installed above the wetland devices $(0.5 \mathrm{~m}$ higher than the surface of the wetland substrate) to monitor the level of $\mathrm{HCHO}$ volatilized into the air.

\section{Calculation and Statistical Analysis}

Removal rates of $\mathrm{HCHO}$ were calculated with the following equation:

$$
\text { HCHO removal }(\%)=\frac{C_{0}-C}{C_{0}} \times 100 \%
$$

...where $\mathrm{C}_{0}$ is the initial $\mathrm{HCHO}$ concentration in synthetic wastewater, and $\mathrm{C}$ is the $\mathrm{HCHO}$ concentration in effluents.

Five replicates were conducted for each different experimental condition (parameter changes, including initial $\mathrm{HCHO}$ concentration, $\mathrm{pH}$, and DO). Statistical analysis of HCHO removal was conducted by the analytical software SPSS 20.0. The significant differences were assessed by Duncan's multiple range test at $\mathrm{P}<0.05$.

\section{Results and Discussion}

\section{Formaldehyde Removal by Single TFCW}

Within $1 \mathrm{~m}^{3}$ around the TFCWs, the average $\mathrm{HCHO}$ concentration in the air was $0.008 \mathrm{mg} \mathrm{m}^{-3}$ throughout the experiments, which was far below the air quality standard for $\mathrm{HCHO}$ stipulated with the World Health Organization $\left(0.1 \mathrm{mg} \mathrm{m}^{-3}\right)$ [14]. Therefore, the volatilization of $\mathrm{HCHO}$ in this study can be ignored. Fig. 2 shows the time courses of $\mathrm{HCHO}$ removal in $\mathrm{PCW}$ and UCW, with the initial $\mathrm{HCHO}$ concentration of 25 to $100 \mathrm{mg} \mathrm{L}^{-1}$ in period 1 . In consideration that the atmospheric reoxygenation mainly occurred in the upper part of the CW [15], and different DO distribution was generally presented vertically from top to bottom for a vertical flow CW. The removal efficiencies of $\mathrm{HCHO}$ between the upper and lower part were also compared.

It is generally accepted that vegetation has the potential to remove the water-soluble $\mathrm{HCHO}$ by absorbing, transporting, and metabolizing [16]. Besides, the roots can maintain favorable ecological circumstances for rhizospheric microorganisms [17], which contributed to the degradation of organic contaminants. However, data from Fig. 2a) and b) show that the HCHO removal efficiencies were similar between the upper part of PCW (U-PCW) and UCW (U-UCW). An initial HCHO concentration of $25 \mathrm{mg} \mathrm{L}^{-1}$ could be removed after 5-h treatment. More than $98 \%$ of the $\mathrm{HCHO}$ was removed from U-PCW and U-UCW within 8 hours when the initial $\mathrm{HCHO}$ concentration was $50 \mathrm{mg} \mathrm{L}^{-1}$. By contrast, Fig. 2c) and d) show an apparent 
a)

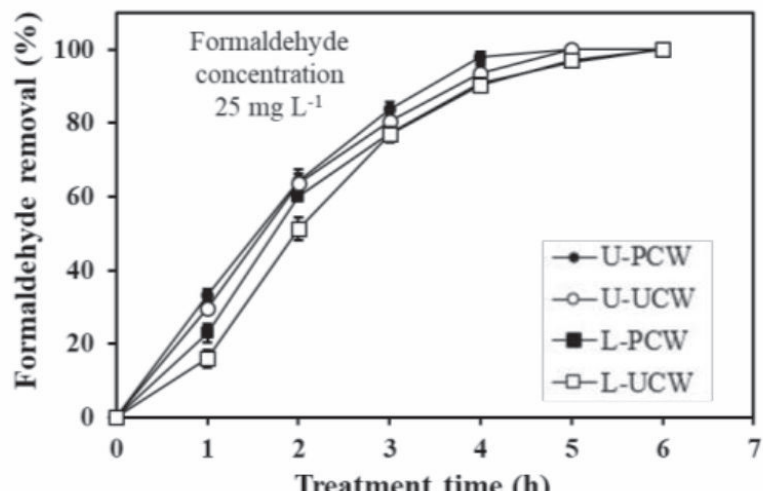

c)

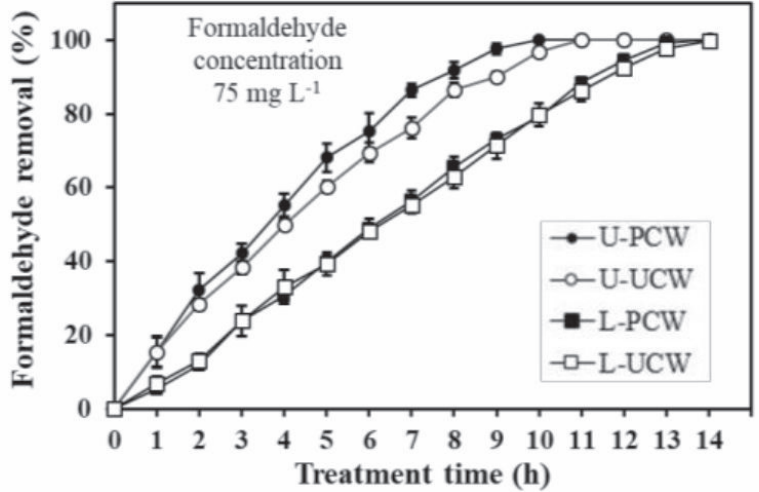

b)

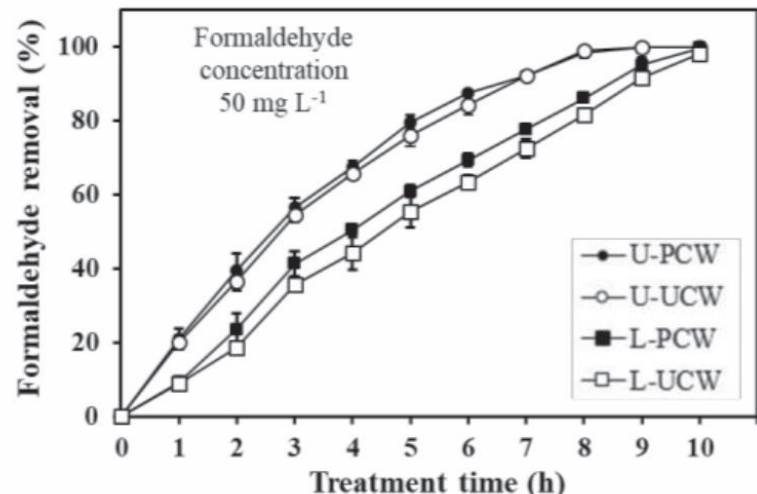

d)

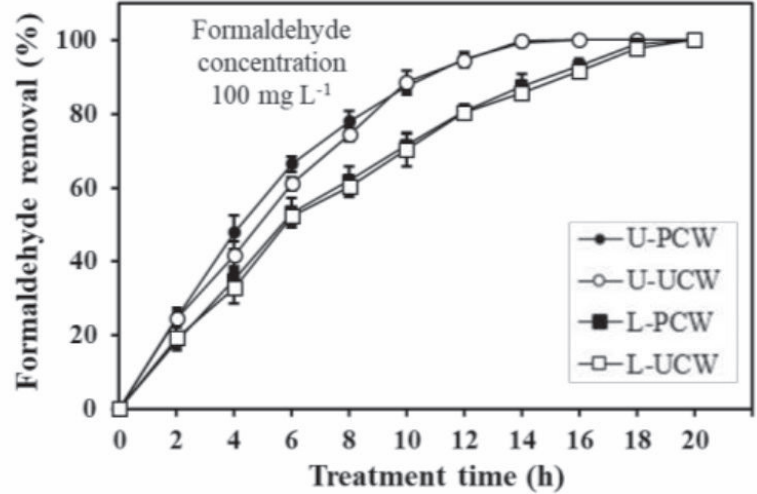

Fig. 2. HCHO removal performance in TFCW with the initial FA concentration of a) 25 , b) 50, c) 75 , and d) $100 \mathrm{mg} \mathrm{L}^{-1}$, respectively.

difference in $\mathrm{HCHO}$ removal between the U-PCW and U-UCW. As the influent HCHO concentration was 75 and $100 \mathrm{mg} \mathrm{L}^{-1}$, U-PCW had a significantly higher $\mathrm{HCHO}$ removal than those in U-UCW during the $4^{\text {th }}$ to $9^{\text {th }}$ hours and the $2^{\text {nd }}$ to $8^{\text {th }}$ hours of the treatment, respectively $(\mathrm{P}<0.05)$. These results indicate that wetland vegetation (Canna indices $\mathrm{L}$.) promoted $\mathrm{HCHO}$ removal, while the primary pathway to remove $\mathrm{HCHO}$ from CWs was microbiological degradation.

For the TFCWs of both non-vegetated and vegetated, the effluents from the upper outlets exhibited remarkably lower HCHO contents, compared with those from the corresponding lower outlets. For example, with an influent $\mathrm{HCHO}$ concentration of $100 \mathrm{mg} \mathrm{L}^{-1}$, the $\mathrm{HCHO}$ could be removed within 14 hours in U-PCW, while for the lower part of PCW (L-PCW), it took 20 hours. This observation was corroborating to the previous research that the $\mathrm{HCHO}$ was mainly removed by the upper portion of a biofilter bed [18]. Previous studies have demonstrated that the methylotrophic bacteria, which using $\mathrm{HCHO}$ as the carbon source and molecular oxygen as the electron acceptor, can eventually metabolize $\mathrm{HCHO}$ into $\mathrm{CO}_{2}$ [19]. Also, it has been reported that the atmospheric reoxygenation generally occurred in the upper portion of the TFCW from 0 to $10 \mathrm{~cm}$ depth [20]. Given the above, it is speculated that the DO level in interstitial water of the wetland substrates might be a key factor, which affects the HCHO biodegradation.
Impacts of Influent pH and DO on Formaldehyde Removal

The impacts of influent $\mathrm{pH}$ and $\mathrm{DO}$ values on $\mathrm{HCHO}$ removal (influent $\mathrm{HCHO}$ concentration: $100 \mathrm{mg} \mathrm{L}^{-1}$ ) were performed in PCW (Fig.3). U-PCW showed generally higher $\mathrm{HCHO}$ removal rates than the lower portion at various initial $\mathrm{pH}$ and $\mathrm{DO}$ conditions. The $\mathrm{HCHO}$ removal increased sharply when the $\mathrm{pH}$ increased from 5.1 to 7.2. The corresponding increases for U-PCW and L-PCW were 38.6 and $33.9 \%$, respectively. However, a decreased HCHO removal performance was obtained in PCW when the influent $\mathrm{pH}$ over 8.09. These results indicate that the HCHO removal was greatly affected by the influent $\mathrm{pH}$, and a neutral or weakly alkaline condition was conducive to $\mathrm{HCHO}$ removal (Fig. 3a). According to Fig. 3b), PCW had a low performance of $\mathrm{HCHO}$ removal with the initial DO values of 2.0 and $3.1 \mathrm{mg} \mathrm{L}{ }^{-1}$, while the DO concentration of $4.1 \mathrm{mg} \mathrm{L}^{-1}$ allowed a removal efficiency of $55.36 \%$ in U-PCW and $49.33 \%$ in L-PCW, respectively. A further increase in influent DO concentration showed a limited contribution to HCHO removal.

\section{Formaldehyde Removal by Two-Stage Cyclic TFCW}

The tidal operation was generally considered a reliable strategy for the reoxygenation of CWs [21]. Based on the exploration of HCHO removal in single TFCWs, a two-stage cyclic TFCW (t-TFCW) was 
a)

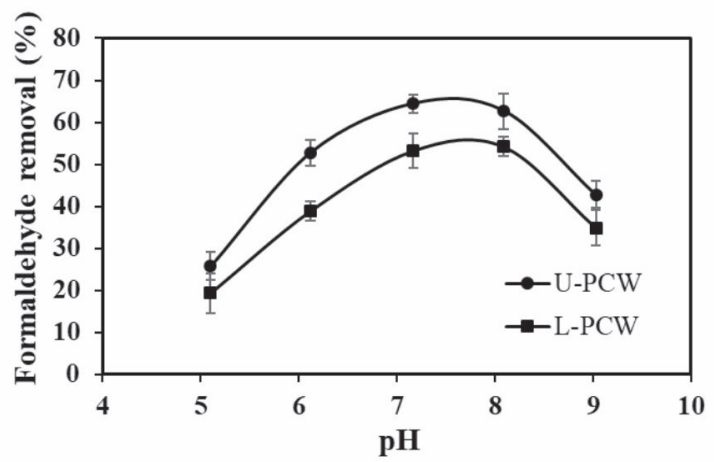

b)

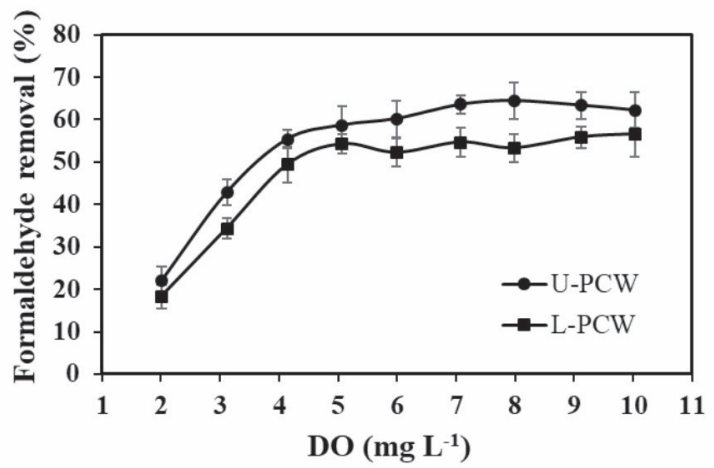

Fig. 3. Impact of influent $\mathrm{pH}$ (a) and DO (b) on HCHO removal of the TFCW (the initial HCHO concentration was around $100 \mathrm{mg} \mathrm{L}^{-1}$, and the HRT was $6 \mathrm{~h}$ ). constructed to upgrade the HCHO removal. As shown in Fig. 1c), the synthetic wastewater was circulated between CW1 and CW2, and each individual TFCW can be atmospheric reoxygenation during the idle time (1 hour) after 1-hour operation. Fig. 4a) shows that stable and efficient $\mathrm{HCHO}$ removal was achieved in the t-TFCW throughout the operation process (50 treatment cycles). With an influent $\mathrm{HCHO}$ of $98.4 \pm 1.8 \mathrm{mg} \mathrm{L}^{-1}$, t-TFCW obtained a HCHO removal of $52.5 \%$ within 2 hours, and $98.1 \%$ of the $\mathrm{HCHO}$ could be removed after a 6-hour treatment (Fig. 4b).

\section{Conclusions}

The HCHO removal in TFCW mainly depended on microbiological degradation, and wetland vegetation was conducive to $\mathrm{HCHO}$ removal. Aerobic condition (DO concentration $>4 \mathrm{mg} \mathrm{L}^{-1}$ ) and neutral/weak alkaline $\mathrm{pH}$ (approximately 7-8) was favorable for the HCHO removal. This study also demonstrated that $\mathrm{HCHO}$ could be efficiently removed by a two-stage cyclic TFCW, which was proposed as an environmentfriendly and effective strategy for $\mathrm{HCHO}$ containing wastewater treatment. Further studies should focus on the microbial mechanisms to support the preliminary findings of this study.

a)

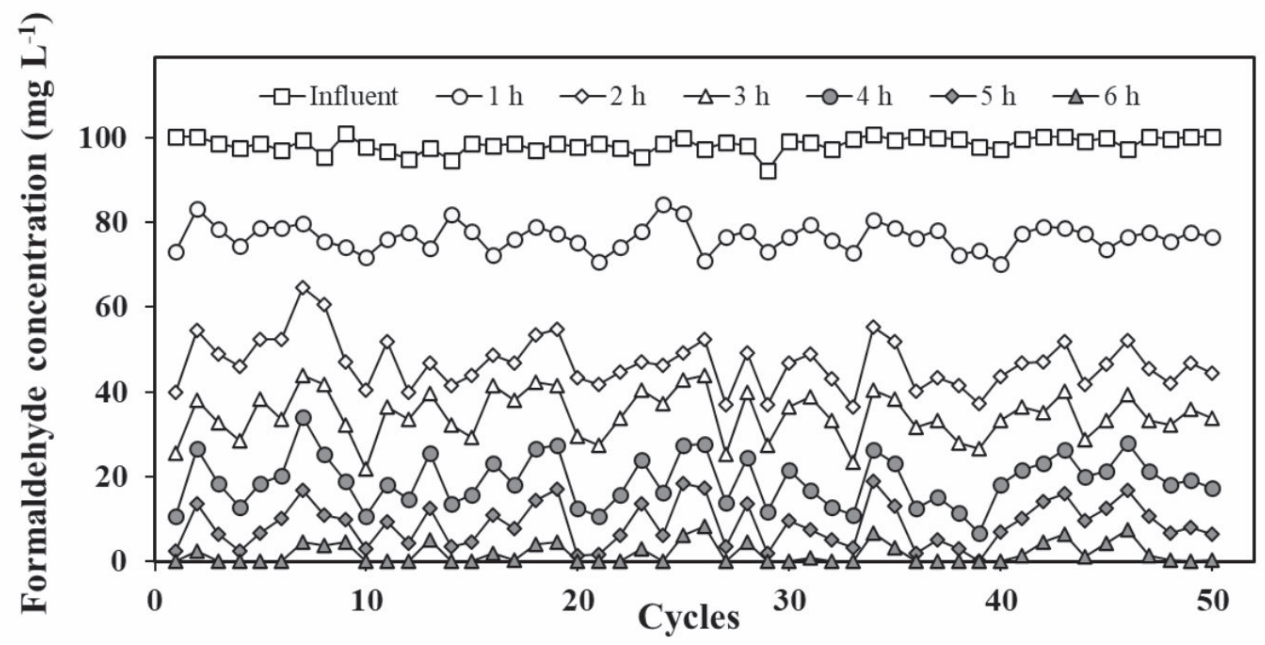

b)

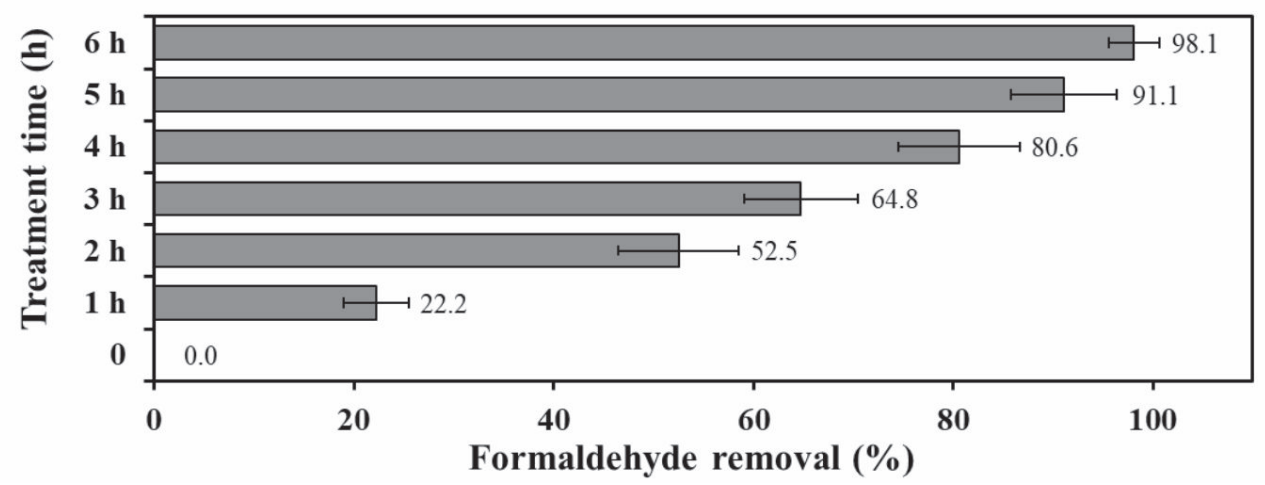

Fig. 4. Residual HCHO concentration a) and average HCHO removal b) in the effluents of the two-stage cyclic TFCW. The treatment times were $1,2,3,4,5$, and $6 \mathrm{~h}$, respectively. The values in figure $\mathrm{b})$ are means $\pm \operatorname{SD}(\mathrm{n}=50)$. 


\section{Acknowledgements}

This work was supported by the National Key Research and Development Project of China (Grant No. 2019YFC0408604); the National Natural Science Foundation of China (Grant No. 51679041 and 51909034); the Fundamental Research Funds for the Central Universities (Grant No. 2232018D3-22, No.2232019D3-21).

\section{Conflict of Interest}

The authors declare no conflict of interest.

\section{References}

1. IARC. Formaldehyde, 2-butoxyethanol and 1-tertbutoxypropan-2-ol. Iarc Monogr Eval Carcinog Risks Hum, 88, 1, 2006.

2. TANG X.J., BAI Y., DUONG A., SMITH M.T., LI L.Y., ZHANG L.P. Formaldehyde in China: production, consumption, exposure levels, and health effects. Environment International, 35, 1210, 2009.

3. DONCZO B., GUTTMAN A. Biomedical analysis of formalin-fixed, paraffin-embedded tissue samples: The Holy Grail for molecular diagnostics. Journal of Pharmaceutical and Biomedical Analysis, 155, 125, 2018.

4. SURESH S., KANTE K., FINI E.H., BANDOSZ T.J. Combination of alkalinity and porosity enhances formaldehyde adsorption on pig manure -derived composite adsorbents. Microporous and Mesoporous Materials, 286, 155, 2019.

5. AFKHAMI A., BAGHERI H., MADRAKIAN T. Alumina nanoparticles grafted with functional groups as a new adsorbent in efficient removal of formaldehyde from water samples. Desalination, 281, 151, 2011.

6. BAI B., QIAO Q., LI J., HAO J. Progress in research on catalysts for catalytic oxidation of formaldehyde. Chinese Journal of Catalysis, 37, 102, 2016.

7. GONG Y., ZHOU X., MA X., CHEN J. Sustainable removal of formaldehyde using controllable water hyacinth. Journal of Cleaner Production, 181, 1, 2018.

8. MEI X., GUO Z., LIU J., BI S., LI P., WANG Y., SHEN W., YANG Y., WANG Y., XIAO Y., YANG X., LIU Y., ZHAO L., WANG Y., HU S. Treatment of formaldehyde wastewater by a membrane-aerated biofilm reactor (MABR): The degradation of formaldehyde in the presence of the cosubstrate methanol. Chemical Engineering Journal, 372, 673, 2019.
9. NAROŻNIAK-RUTKOWSKA Ł.M.A., PAJOR E. Effect of a static magnetic field of $7 \mathrm{mT}$ on formaldehyde biodegradation in industrial wastewater from ureaformaldehyde resin production by activated sludge. Bioresource Technology, 132, 78, 2013.

10. PEREIRA N.S., ZAIAT M. Degradation of formaldehyde in anaerobic sequencing batch biofilm reactor (ASBBR). Journal of Hazardous Materials, 163, 777, 2009.

11. DU X., XU Z., LI J., ZHENG L. Characterization and removal of dissolved organic matter in a vertical flow constructed wetland. Ecological Engineering, 73, 610, 2014.

12. LEUNG J.Y.S., CAI Q., TAM N.F.Y. Comparing subsurface flow constructed wetlands with mangrove plants and freshwater wetland plants for removing nutrients and toxic pollutants. Ecological Engineering, 95, 129, 2016.

13. MELIÁN J.A.H., MÉNDEZ A.O., ARAÑA J., DÍAZ O.G., RENDÓN E.T. Degradation and detoxification of formalin wastewater with aerated biological filters and wetland reactors. Process Biochemistry, 43, 1432, 2008.

14. WHO. WHO Guidelines for Indoor Air Quality: Selected Pollutants. World Health Organization: Geneva, 2010.

15. LIU H., HU Z., ZHANG J., NGO H.H., GUO W., LIANG S., FAN J., LU S., WU H. Optimizations on supply and distribution of dissolved oxygen in constructed wetlands: A review. Bioresource Technology, 214, 797, 2016.

16. SONG Z.B., XIAO S.Q., YOU L., WANG S.S., TAN H., LI K.Z., CHEN L.M. C1 metabolism and the Calvin cycle function simultaneously and independently during $\mathrm{HCHO}$ metabolism and detoxification in Arabidopsis thaliana treated with HCHO solutions. Plant Cell \& Environment, 36, 1490, 2013.

17. WANG Z., PEI J., ZHANG J.S. Experimental investigation of the formaldehyde removal mechanisms in a dynamic botanical filtration system for indoor air purification. Journal of Hazardous Materials, 280, 235, 2014.

18. XU Z.J., NA Q., WANG J.G., HUA T. Formaldehyde biofiltration as affected by spider plant. Bioresource Technology, 101, 6930, 2010.

19. SPELLMAN F.R. Handbook of Water and Wastewater Treatment Plant Operations, 3rd ed.; CRC Press/Taylor \& Francis Group, 2014.

20. YE J., WANG L., LI D., HAN W., YE C. Vertical oxygen distribution trend and oxygen source analysis for verticalflow constructed wetlands treating domestic wastewater. Ecological Engineering, 41, 8, 2012.

21. CHEN Z., VYMAZAL J., KUSCHK P. Effects of tidal operation on pilot-scale horizontal subsurface flow constructed wetland treating sulfate rich wastewater contaminated by chlorinated hydrocarbons. Environmental Science and Pollution Research, 24, 1042, 2017. 